
ISSN : 2615-1995, E-ISSN : 2615-0654

J. Madani., Vol. 3, No. 1, Maret 2020 (132 - 140)

(C)2018 Lembaga Kajian Demokrasi

\title{
Ergonomi Partisipasi Dalam Mempromosikan Pengelolaan Sampah Mandiri dan Daur Ulang Kemasan Tetra Pak
}

\author{
Helena Juliana Kristina \\ Fakultas Teknik, Universits Tarumanagara \\ julianak@ft.untar.ac.id \\ Wilson Kosasih \\ Fakultas Teknik, Universits Tarumanagara \\ wilsonk@ft.untar.ac.id \\ Lithrone Laricha \\ Fakultas Teknik, Universits Tarumanagara \\ lithrones@ft.untar.ac.id
}

\begin{abstract}
Abstrak
Dalam PERPRES NO 97 thn 2017 yang berisi tentang kebijakan dan strategi pengolahan sampah, mentargetkan sampai thn 2025, terjadi penanganan sampah 70\% dan pengurangannya sampai $30 \%$. Hal ini dapat dilakukan dalam konteks pengelolaan sampah yang menggunakan prinsip 3 R: Reduce, Reuse dan Recycle. Untuk mencapai angka penurunan sampah 15\% sangat sulit jika kesadaran peduli sampah tidak dimulai dari anggota masyarakat Indonesia sendiri. Sirkular ekonomi (circular economy) telah mulai diuji coba sebagai salah satu sistem ekonomi ramah lingkungan. PT Tetra Pak Indonesia adalah salah satu perusahaan yang sudah menerapkan praktik bisnis yang berwawasan lingkungan. Dalam penelitian ini, dilakukan eksperimen didaktik dengan pendekatan konsep ergonomi partisipasi guna mengukur seberapa besar keinginan para partisipan terkait untuk berpartisipasi mewujudkan sistem sirkular ekonomi, dan secara khusus mempromosikan pengelolaan sampah mandiri dan daur ulang kemasan tetra pak. Hasil penelitian ini, diharapkan akan berguna untuk mengembangkan inovasi-inovasi yang berguna dalam meningkatkan kualitas pemberdayaan program sirkular ekonomi.
\end{abstract}

Kata Kunci : Ergonomi Partisipasi, Pengelolaan sampah, Daur Ulang, Tetra Pak, Sirkular Ekonomi

\begin{abstract}
In PERPRES NO 97year 2017 which contains policies and strategies for waste management, targeting until the year 2025, 70\% of waste handling and reduction of up to 30\%. This can be done in the context of waste management using the $3 R$ principle (Reduce, Reuse and Recycle). To achieve a $15 \%$ reduction in waste is very difficult if awareness of caring about waste does not start with members of the Indonesian community itself. Circular economy has begun to be tested as one of the environmental friendly economic systems. PT Tetra Pak Indonesia is one of the companies that has implemented business practices with environment insightful. In this research, a didactic experiment had been done with the concept of participatory ergonomics approach to measure how much the participants want to participate in realizing an economic circular system, and specifically promoting independent waste management and recycling of tetra pak packaging. The results of this study are expected to be useful for developing innovations in improving the quality of empowerment of economic circular programs.
\end{abstract}


Keywords : Ergonomics Participation, Waste Management, Recycling, Tetra Pak, Circular Economy

\section{PENDAHULUAN}

Dalam Perpres No. 97 Tahun 2017 tentang kebijakan dan strategi pengolahan sampah, pemerintah mentargetkan sampai tahun 2025, terjadi penanganan sampah $70 \%$ dan pengurangannya sampai $30 \%$. Hal ini dapat dilakukan dalam konteks pengelolaan sampah yang menggunakan prinsip 3 R: Reduce, Reuse, dan Recycle. Data Sistem Informasi Pengelolaan Sampah Nasional Kementerian Lingkungan Hidup dan Kehutanan Republik Indonesia mencatat, sampah yang ditimbun di TPA Kota Tangerang mencapai 928 ton per hari di mana 105 tonnya belum dapat dikelola. Sedangkan di DKI Jakarta, jumlah sampah yang ditimbun di TPA mencapai 11 ribu ton per hari dan 273 ton masih belum dapat dikelola. (Sistem Informasi Pengelolaan Sampah Nasional 2018)

Menurut Direktur Jenderal Pengelolaan Sampah, Limbah, dan Bahan Beracun Berbahaya (B3) Rosa Vivien Ratnawati, volume sampah rumah tangga dan sejenisnya tahun 2018 telah mencapai 66.5 juta ton. Berdasarkan Badan Pusat Statistik Lingkungan Hidup Indonesia penurunan sampah sejak tahun 2012 hanya 2\%-3\% (Badan Pusat Statistik 2017).

Dalam jangka panjang, industri dihimbau sudah mengarahkan program produksi bersihnya yang mengarah kepada keberlanjutan. Dengan menggunakan prinsip ekonomi sirkular, di mana nilai produk dan material dijaga dan dimanfaatkan selama mungkin, sehingga timbunan sampah dapat dibatasi sekecil mungkin. Inti dari ekonomi sirkular adalah menyeimbangkan aspek lingkungan dan ekonomi, sehingga dapat dijalankan bersama secara berkelanjutan.

Teori circular economy sebagai ide tujuan dari daur ulang itu sendiri bagi perusahaan. Circular economy memiliki pengertian "regenerative system in which resource input and waste, emission and energy leakage are minimized by slowing, closing, and narrowingenergyand materialloops; thiscan be achieved through long-lasting resign, maintenance, repair, reuse, remanufacturing, refurbishing, recycling, and upcycling" (Geissdoefer, 2017).

Semakin mahalnya sumber daya alam, sedangkan ekonomi harus tetap tumbuh, maka segala sesuatu nilai sumber daya ekonomi, termasuk yang sudah menjadi sampah, harus dimanfaatkan, agar ketika masa pakainya habis dapat di daur ulang dan di manfaatkan kembali berkalikali, oleh industri lain (Sumargi Arief, 2018). GAPMMI atau ASPADIN juga sudah mengerti tentang konsep BDU: Bisa Daur Ulang dan LDU: Layak Daur Ulang. Tetapi untuk mewujudkan hal ini tentunya membutuhkan waktu, dan yang terpenting adalah pelaksanaan sistem manajemen sampah yang dijalankan serius seperti UU No 18 tahun 2018 pasal 13 dan 45, yang telah 10 tahun dikeluarkan, namun pelaksanaannya disetiap daerah dengan PERDA yang masih belum andal. (Henky Wibawa, 2019)

Kemasan karton bekas minuman merupakan bahan baku yang bernilai bagi industri lain, seperti industri kertas daur ulang, furniture, mebel, roofing, dan lainnya. Tetra Pak telah secara bersama mengembangkan infrastruktur pengumpulan ini sejak tahun 2005 yang di inisiasi bersama BBPK (Balai Besar Pulp dan Kertas), dengan mitra pengumpul seperti EcoBali, Yapsi, Armada Kemasan Nusantara, Waste4Change, Bina Usaha Mandiri, yang mana saat ini telah mencapai lebih dari 100 collection points di pulau Jawa-Bali. Mitra pabrik daur ulangnya, terdapat di Tangerang dan Mojokerto.Tetra Pak Indonesia membantu mitra pendaur dengan setup mesin yang bekerja secara efektif, khusus untuk mendaur ulang Kemasan karton bekas minuman, dan memberikan rekomendasi solusi efisien. Sebagai hasil, pada tahun 2017, Tetra Pak telah berhasil mengolah lebih dari 6,600 tons kemasan karton bekas minuman yang terkumpul (Andreanto Reza, 2018). Adapun contoh produk daur ulang kemasan tetra pak dapat dilihat pada Gambar 1. 


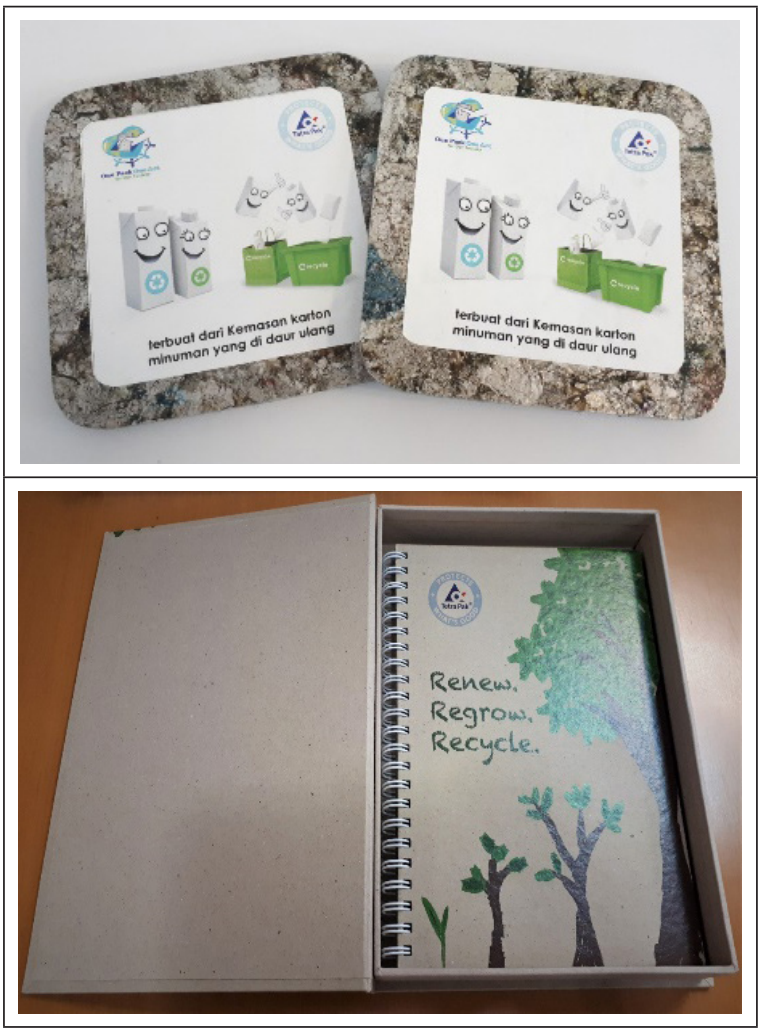

Gambar 1. Contoh Hasil Produk Daur Ulang Kemasan Tetra Pak

Kristina J Helena dkk, 2018 telah mencoba membuatkan sistem percontohan sirkular ekonomi untuk membangun jejaring rantai pasok daur ulang kemasan karton tetra pak di Tangsel dengan pendekatan konsep ergonomi partisipasi. Jumlah bank sampah di Tangsel yang berpartisipasi ada 16 bank sampah. Di akhir projek tersebut, pengepul percontohan juga resmi menjadi mitra daur ulang PT. Tetra Pak Indonesia, dengan nama SAMPAHQU.

Pendekatan ergonomi partisipasi, mengharapkan seluruh peserta memiliki keterlibatan langsung dalam perencanaan dan pelaksanaan tugas-tugas mereka, seperti adanya rapat yang bertujuan untuk saling bertukar pikiran maupun menyumbangkan ide-ide yang dapat digunakan untuk menyelesaikan tugas dengan baik dan sempurna (Vink et.all, 2008). Partisipasi merupakan terlibatnya orang secara mental dan emosional di dalam satu komunitas yang merangsang mereka untuk berkontribusi kepada tujuan kelompok dan berbagi tanggung jawab untuk apa yang dihasilkannya (Manuaba, 1999). Ergonomi partisipasi memerlukan kondisi tertentu untuk bisa berlangsung secara ber- hasil dan sukses yaitu adanya waktu yang cukup untuk ikut terlibat, manfaat yang diperoleh lebih besar dari pada biaya yang dikeluarkan, dan relevan dengan kebolehan orang yang dilatih untuk menangani masalah, serta cukup waktu berkomunikasi, cara berkomunikasi yang menguntungkan kedua belah pihak, tidak adanya perasaan dipaksa oleh pihak lain dan masih berada dalam wilayah kebebasan bekerja.

Komunitas juga selalu memiliki banyak kepentingan dan pelaku, dan berkaitan dengan entitas entitas lain dalam skala yang berbeda (Clayton Susan \& Gene Myers, 2014). Orang atau partisipan yang bergabung dalam komunitas peduli sampah, biasanya mempunyai minat, nilai dan keyakinan bahwa ada nilai ekonomi sosial yang didasarkan pada prinsip kebaikan bersama dari sampah yang dikelolanya, bagi kepentingan bersama anggota masyarakat dan lingkungan di sekitarnya. Komunitas ini membutuhkan partisipasi aktif dari penggurusnya untuk dapat berkelanjutan. Komunitas Saung Babe di Serpong Terrace RT03, RW09, Kelurahan Buaran, Kecamatan Serpong, Tangerang Selatan telah mulai mengumpulkan dan memilah sampahnya. Bermula dari kondisi defisit kas RT, mereka mendapat inisiatif untuk mencoba mengumpulkan barang bekas (botol plastik, kardus, dan lainnya). Di luar dugaan ternyata inisiatif ini berjalan cukup baik, setiap 1 sampai 2 bulan sekali, mereka mendapat Rp200.000 - sampai Rp300.000.

Meskipun masih banyak kekurangan, sampah yang dikumpukan masih banyak tercampur, dan partisipasi hanya segelintir. Dari jumlah KK sekitar 40-50, hanya 15-20 KK yang ikut berpartisipasi dalam kegiatan ini. Operasinya adalah pada hari $\mathrm{H}$, warga janjian di satu titik untuk memilah sampah dan menjualnya pada pelapak, dapat dilihat pada gambar 2. Pada tahap lebih lanjut, mereka mengumpulkan hasil pulungan, ditabung kas RT dan sedikit demi sedikit mereka bisa membuat saung yang agak permanen. Lokasi saung mereka ditempat yang agak kosong di perumahan tersebut dan dengan modal batu bekas aspal jalanan, mereka alasi, sehingga saung bisa berdiri (gambar 3).

Hasil pulungan setahun terkumpul 3 jutaan 
untuk modal membuat rangka yang agak permanen. Kerja para partisipan tidak hanya sampai disitu saja, mereka mulai mengedukasi warga untuk belajar memilah sampah dalam beberapa kategori, dan hasil pilahannya di simpan di saung Babe (Barang Bekas). Saat ini, terdapat permasalahan bahwa pengepul sebelumnya kadang tidak datang untuk mengangkut sampah, dan juga jumlah partisipan warga belum seluruhnya ikut serta. Warga juga belum mengetahui nilai dari sampah kemasan tetra pak, padahal jenis sampah ini cukup banyak di rumah warga.

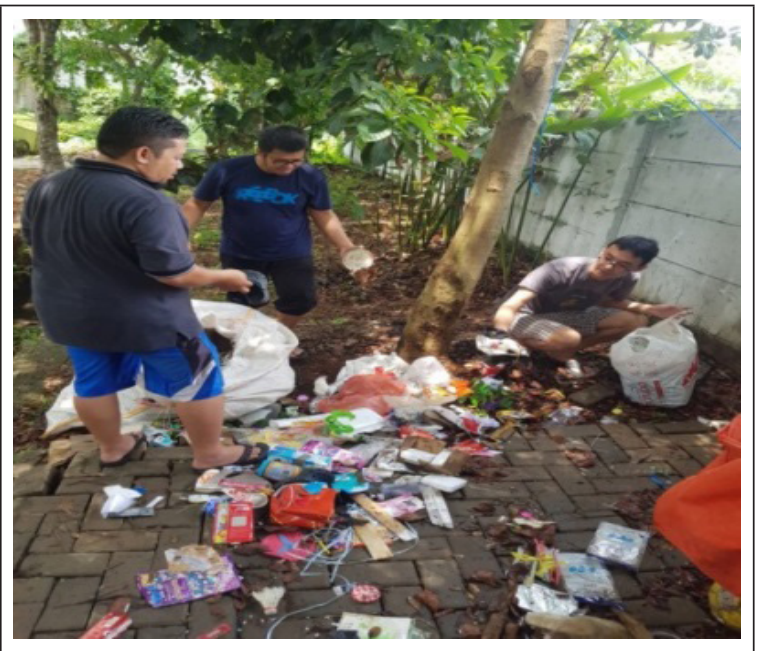

Gambar 2. Warga Memilah Sampah yang Bernilai Ekonomis

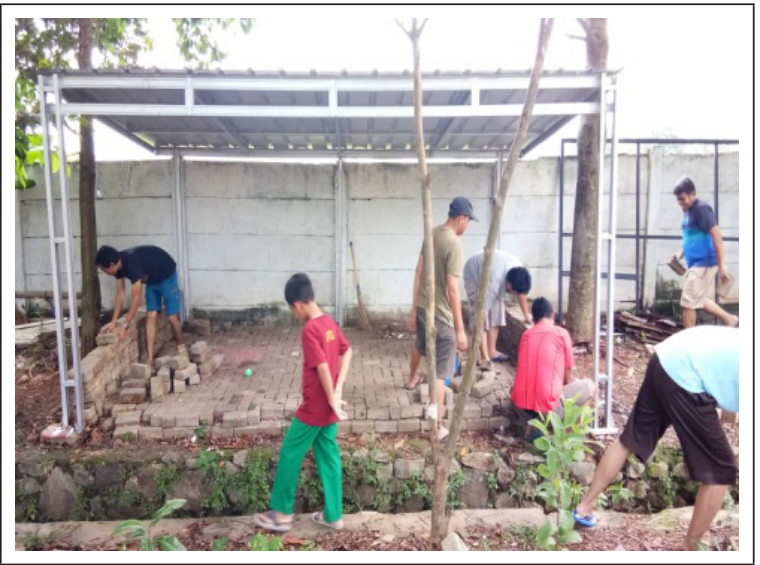

Gambar 3. Warga Berpartisipasi Membangun Saung Sampah Babe

Dalam penelitian ini, dilakukan eksperimen didaktik dengan pendekatan konsep ergonomi partisipasi guna mengukur seberapa besar keinginan para partisipan terkaituntukberpartisipasi mewujudkan sistem sirkular ekonomi, dan secara khusus mempromosikan pengelolaan sampah mandiri dan daur ulang kemasan tetra pak.

\section{METODE}

Tipe penelitian adalah penelitian eksperimen, dikarenakan datanya belum pernah ada, dan harus diciptakan terlebih dahulu. Hasil penelitian ini, diharapkan akan berguna untuk mengembangkan inovasi-inovasi yang berguna dalam meningkatkan kualitas pemberdayaan program sirkular ekonomi. Projek ini adalah bentuk kegiatan partisipasi terstruktur, dimana akan disosialisasikan pada semua partisipannya, harapan dan tujuan projek dengan harapan terjadi sinergi pemberdayaan, dimana masing-masing partisipan mau memberikan/menyumbangkan apa yang bisa diberikan untuk keberhasilan projek. Durasi projek berlangsung 4 bulan, dari Maret 2019 sampai Juni 2019. Adapun setelah projek selesai, diharapkan model sirkular ekonomi di RT percontohan ini, tetap dapat berjalan sendiri dengan dibantu mitra SAMPAHQU.

Jenis Desain Eksperimen: One Group After Only Design. Pada desain ini, hanya satu kelompok (one group) eksperimen, yaitu kelompok partisipasi (Tabel 1), partisipan dalam kelompok menerima sebuah treatment (perlakukan), yaitu informasi edukasi bahwa dibutuhkan partisipasi dan kerjasama untuk keberhasilan kegiatan pengelolaan sampah mandiri di saung Babe RT 03 Serpong Terrace sebagai projek percontohan pertama di perumahan BSD Tangsel yang mayoritas warganya adalah kalangan me-

\begin{tabular}{|c|c|}
\hline Nama Partisipan & $\begin{array}{c}\text { Bentuk Keterlibatan Partisipasi } \\
\text { yang Diharapkan di Awal Persiapan Projek }\end{array}$ \\
\hline $\begin{array}{l}\text { Penggurus/ FORKOM } \\
\text { RT 03 Serpong Terrace } \\
\text { BSD Tangsel }\end{array}$ & $\begin{array}{l}\text { - Mensosialisasikan pada warganya untuk } \\
\text { kegiatan pengolahan sampah mandiri } \\
\text { dengan mitra SampahQU, berupa pemilahan, } \\
\text { penimbangan dan penabungan sampah, } \\
\text { khususnya mengusung promosi daur ulang } \\
\text { kemasan tetra pak. } \\
\text { - Melaporkan hasil penimbangan sampah } \\
\text { kepada tim abdimas }\end{array}$ \\
\hline PT. Tetra Pak Indonesia & $\begin{array}{l}\text { - Membantu projek dengan produk hasil daur } \\
\text { ulang tetra pak }\end{array}$ \\
\hline SAMPAHQU & $\begin{array}{l}\text { - Membantu projek dengan menginformasikan } \\
\text { kepada penggurus RT jenis sampah yang } \\
\text { bernilai ekonomis dan diterima di SAMPAHQU } \\
\text { - Hadir tepat waktu untuk menimbang dan } \\
\text { mengangkut sampah untuk di daur ulang } \\
\text { - Dibantu } 2 \text { bank sampah (BS Blian dan BS } \\
\text { Amarapura) untuk menyemangati kegiatan } \\
\text { projek ini }\end{array}$ \\
\hline $\begin{array}{l}\text { Inkubator Peduli Sampah } \\
\text { Cintai Bumi }\end{array}$ & - Membantu publikasi projek dan jejaring mitra \\
\hline Tim Abdimas TI UNTAR & $\begin{array}{l}\text { - Mengkoordinasi jalannya projek agar tujuan } \\
\text { tercapai }\end{array}$ \\
\hline
\end{tabular}


nengah atas, dan setelah itu (after only) dilakukan pengukuran dampak treatment tersebut pada variabel dependen, yaitu hasil kerjasama dan sinergi dalam projek. Dalam projek ini, memungkinkan mengambil segala tindakan/ perlakuan yang dianggap perlu untuk mensukseskan projek dengan prinsip continuous improvement, dikarenakan terkait dengan eksperimental desain dalam penelitian edukasi di lapangan.

Prosedur Eksperimen Partisipasi adalah sebagai berikut, dapat dilihat pada Gambar 4.

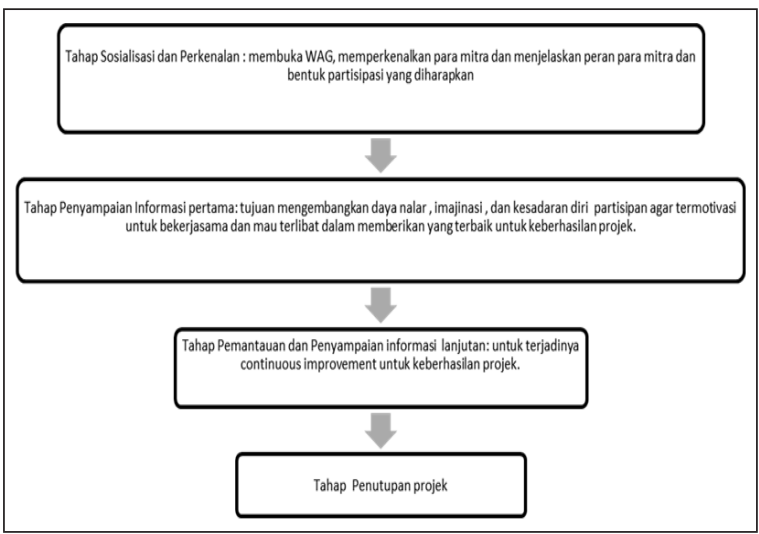

Gambar 4. Prosedur Eksperimen Partisipasi

\section{HASIL dan PEMBAHASAN}

Komunikasi adalah hal yang sangat penting dalam berjejaring dengan para mitra, sebagai wadah untuk memahami bentuk partisipasi apakah yang diminta dan harus diusahakan dalam projek percontohan ini, agar terjadi sinergi yang mengarah pada pencapaian tujuan projek. Untuk komunikasi, digunakan bantuan aplikasi WA grup. Selain menggunakan media aplikasi WA, projek ini juga menggunakan media sosial FB, sebagai alat untuk menginformasikan pada masyarakat luas, bahwa ada kegiatan projek percontohan di masyarakat yang sedang melakukan pengelolaan sampah dengan cara pemilahan, pengumpulan, penimbangan dan penabungan. Platform FB ini juga digunakan untuk mengedukasi dan menginspirasi masyarakat luas agar mulai mau terlibat dalam kegiatan daur ulang. Platform FB yang dipakai adalah akun FB Peduli Sampah Cintai Bumi. Contoh publikasi di FB dapat dilihat pada gambar 5 .

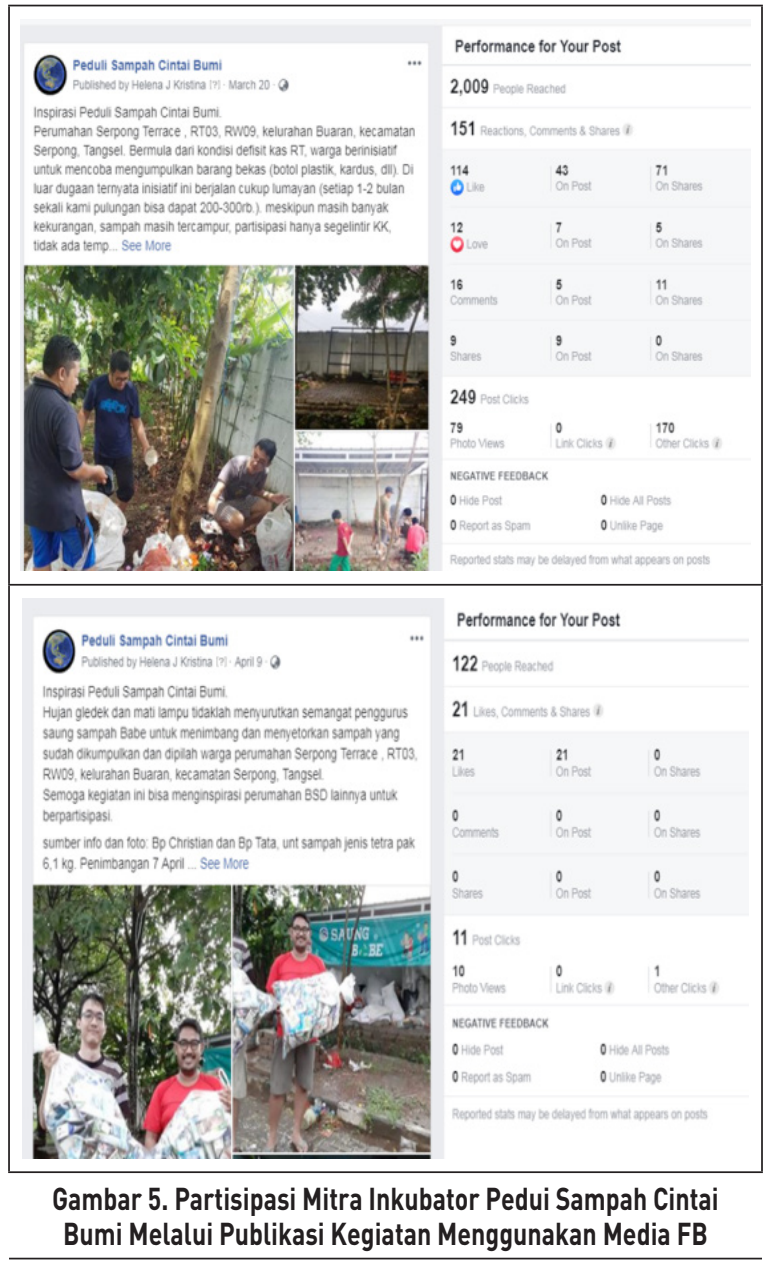

Dalam merancang kualitas menjadi proses layanan dapat dicapai dengan mempertimbangkan kemampuan dan kapasitas kinerja manusia. Semua proses sangat bergantung pada sinergi partisipan untuk bekerja secara efektif dan sukarela guna berpartisiapsi dalam aktualisasi dirinya, untuk memenuhi kebutuhan mereka dalam melakukan tugas. Studi psikologi sosial telah memperlihatkan bahwa, berdasarkan pilihan yang ada, masyarakat lebih menyukai resiprositas sosial (pembagian bersama atau saling menguntungkan) dan kepercayaan (trust) sosial (Clyaton \& Myers, 2014). Hasil partisipasi beberapa mitra ternyata melebihi target yang ditetapkan diawal projek (Tabel 2). 


\begin{tabular}{|c|c|}
\hline Nama Partisipan & Bentuk Keterlibatan Partisipasi Selama Projek \\
\hline $\begin{array}{l}\text { Penggurus/ } \\
\text { FORKOM } \\
\text { RT 03 } \\
\text { Serpong Terrace } \\
\text { BSD Tangsel }\end{array}$ & $\begin{array}{l}\text { - Penggurus RT mensosialisasikan pada warganya } \\
\text { untuk kegiatan pengolahan sampah mandiri dengan } \\
\text { mitra SampahQU, berupa pemilahan, penimbangan } \\
\text { dan penabungan sampah, khususnya mengusung } \\
\text { promosi daur ulang kemasan tetra pak } \\
\text { - Penggurus RT membuat dan memberikan desain } \\
\text { saung Babe untuk keperluan permohonan bantuan } \\
\text { papan polyal kepada PT. Tetra Pak } \\
\text { - Penggurus RT dan warga memperbaiki jembatan } \\
\text { menuju saung Babe agar mudah dilewati warganya } \\
\text { - Pang mau menaruh sampah } \\
\text { Penggurus RT bersedia mempelajari materi edukasi } \\
\text { mengenai nilai kemasan tetra pak dan mengapa perlu } \\
\text { - Pengt berpartisipasi mendaur ulang } \\
\text { bernilai ekonomis termasuk kemasan tetra pak dan } \\
\text { menginformasikan cara pemilahannya } \\
\text { - Penggurus RT membantu menimbang sampah } \\
\text { terpilah dengan mitra SAMPAHQU } \\
\text { - Penggurus RT melaporkan hasil penimbangan } \\
\text { - Penpah kepada tim abdimas } \\
\text { tabungan sampah Saung Babe yang mau dimintakan } \\
\text { dana pencetakan bukunya kepada PT. Tetra Pak } \\
\text { - Penggurus RT berpartisipasi membuat poster edukasi } \\
\text { pada hari lingkungan hidup sedunia } 5 \text { Juni } 2019 \text {, yang } \\
\text { diupload di FB Peduli Sampah Cintai Bumi sebagai } \\
\text { bentuk pernyataan FORKOM RT 03 Serpong Terrace } \\
\text { peduli pada lingkungan hidup }\end{array}$ \\
\hline $\begin{array}{l}\text { PT. Tetra Pak } \\
\text { Indonesia }\end{array}$ & $\begin{array}{l}\text { - Membantu projek dengan produk hasil daur ulang } \\
\text { tetra pak } \\
\text { - Menyiapkan order papan polyal dengan ketebalan } \\
9 \text { mm sebanyak } 20 \text { lembar untuk saung Babe RT } \\
\text { percontohan Serpong Terrace. } \\
\text { - Menyiapkan order cetak buku tabungan sampah } \\
\text { yang telah di desain penggurus RT Saung Babe (Bp } \\
\text { Tata), cetak buku tabungan sampah sebanyak } 50 \\
\text { buku dengan ketebalan halaman 10/buku tabungan } \\
\text { sampah. } \\
\text { - Menyiapkan } 30 \text { godey bag untuk partisipasi RT } \\
\text { percontohan Serpong Terrace. } \\
\text { - Menyiapkan spanduk kegiatan ukuran } 5 \text { m x 0,9 } \\
\text { m yang berisi jenis- jenis tabungan sampah yang } \\
\text { diterima di Saung Babe dan pesan edukasi dari PT. } \\
\text { Tetra Pak Indonesia, mengenai cara penanganan } \\
\text { kemasan tetra pak dari sumbernya dengan } 3 \text { L (LIPAT, } \\
\text { LETAK, LEPAS). }\end{array}$ \\
\hline SAMPAHQU & $\begin{array}{l}\text { - Membantu projek dengan menginformasikan kepada } \\
\text { penggurus RT jenis sampah yang bernilai ekonomis } \\
\text { dan diterima di SAMPAHQU, ada } 71 \text { jenis sampah yang } \\
\text { diterima untuk di daur ulang } \\
\text { - Hadir tepat waktu untuk menimbang dan mengangkut } \\
\text { sampah untuk di daur ulang } \\
\text { - Dibantu } 2 \text { bank sampah di Tangsel ( BS Berlian dan BS } \\
\text { Amarapura) untuk menyemangati kegiatan projek ini, } \\
\text { kedua bank sampah melaporkan di WAG akan jenis } \\
\text { timbangan tetra pak di bank sampah mereka }\end{array}$ \\
\hline $\begin{array}{l}\text { Inkubator Peduli } \\
\text { Sampah Cintai } \\
\text { Bumi }\end{array}$ & $\begin{array}{l}\text { - Membantu publikasi projek dan jejaring mitra } \\
\text { - Membantu mengumpulkan dan menyerahkan sampah } \\
\text { kemasan tetra pak sebagai bentuk partisipasi untuk } \\
\text { menyemangati penggurus RT pada penimbangan } \\
\text { pertama }\end{array}$ \\
\hline $\begin{array}{l}\text { Tim Abdi } \\
\text { UNTAR }\end{array}$ & $\begin{array}{l}\text { - Menghubungi dan mengkoordinasikan partisipasi } \\
\text { mitra SampahQu, PT. Tetra Pak Indonesia, Inkubator } \\
\text { Peduli Sampah Cintai Bumi dan RT percontohan } \\
\text { Serpong Terrace agar tujuan kegiatan abdimas } \\
\text { pemberdayaan masyarakat dan para mitra dapat } \\
\text { tercapai } \\
\text { - Memantau jalannya projek agar tujuan tercapai } \\
\text { - Penyusunan materi ajar kemasan tetra pak untuk } \\
\text { kegiatan pemberian informasi FORKOM RT 03 kepada } \\
\text { warganya }\end{array}$ \\
\hline
\end{tabular}

Beberapa hasil contoh pemberdayaan para mitra melalui partisipasinya selama projek: buku tabungan sampah Saung Babe, dan Ada 18 jenis tabungan sampah terpilah hasil penimbangan pertama dengan mitra SAMPAHQU, dengan total rupiah Rp279.610 dan untuk jenis tetra pak mendapat $6,1 \mathrm{~kg}$, penimbangan kedua dengan total rupiah Rp619.500 dan jenis tetra pak 3,2 kg. Secara keseluruhan penyampaian informasi mengenai kemasan tetra pak yang bisa di daur ulang, yang telah disampaikan oleh FORKOM RT 03 Serpong Terrace pada warganya, cukup berhasil, karena setelah dikonfirmasi tim PKM, dengan sampel warga 28 orang, $86 \%$ menjawab tahu, bahwa kemasan tetra pak bisa didaur ulang. Dan pada umumnya warga mengetahui/menjawab dengan benar contoh-contoh produk hasil daur ulang dari kemasan tetra pak. Hal ini terlihat dari hasil olah kuesioner $33 \%$ menjawab produk kertas daur ulang, 22\% papan polyal, $22 \%$ atap polyal, dan $13 \%$ produk kerajinan tangan daur ulang. Secara rinci, hasilnya dapat dilihat pada olah data di gambar 6 .

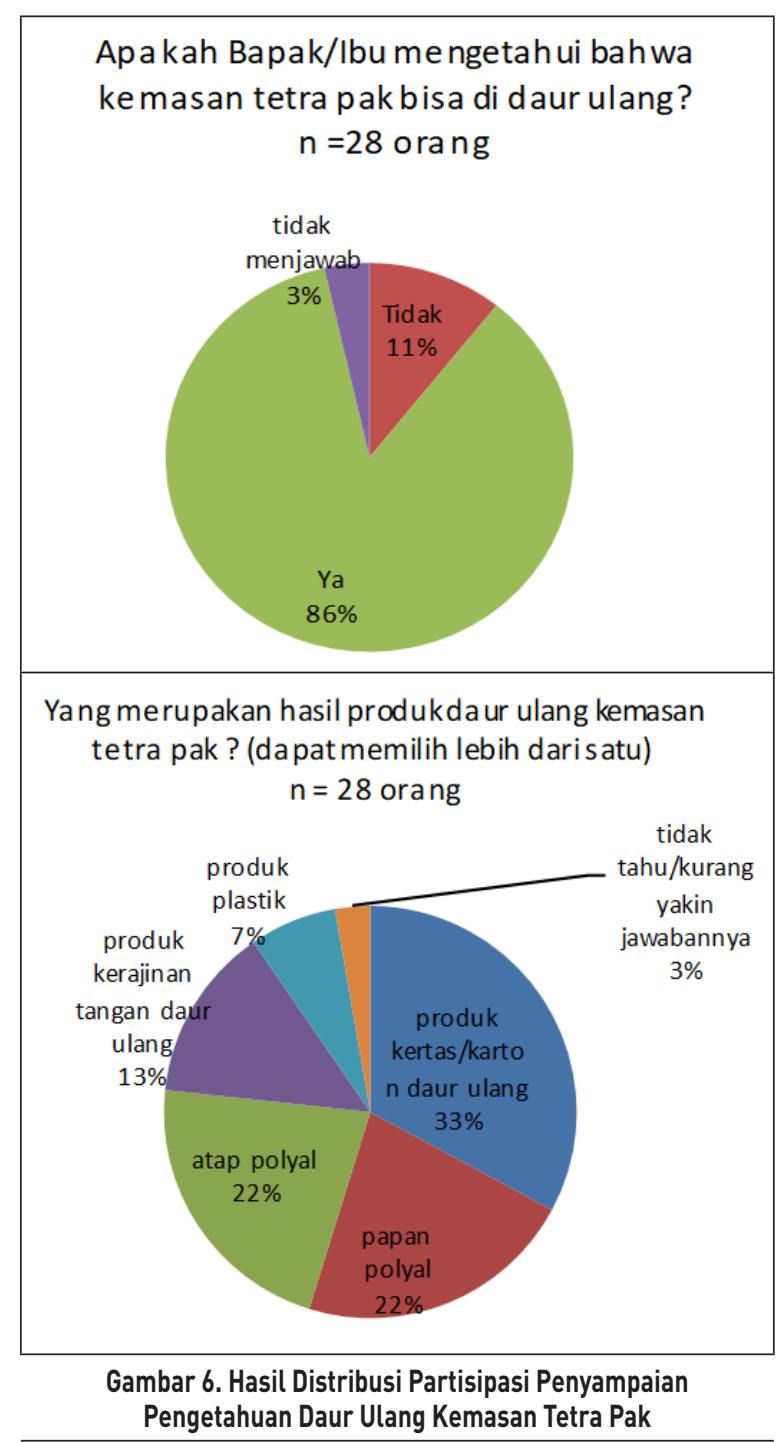


Dari peran partisipasi yang dilakukan warga, terlihat konfirmasi dari hasil kuesioner bahwa $82 \%$ warga ikut berpartisipasi mengumpulkan kemasan tetra pak sebagai salah satu jenis tabungan sampah. Dalam partisipasi praktik perlakukan kemasan tetra pak cara 3L yang diharapkan oleh PT. Tetra Pak Indonesia, sudah cukup terealisasi, terlihat konfirmasi $61 \%$ menyatakan mereka melakukan langkah pengangan kemasan tetra pak ukuran karton besar dengan cara membuka tutupnya, buka lipatannya, memasang kembali tutupnya, dan meletakan di tempat sampah terpilah, dan 35\% melakukan hal yang sama, hanya bedanya mereka memisahkan tutupnya ke tempat pilah lain. Untuk lebih jelasnya dapat dilihat pada gambar 7.

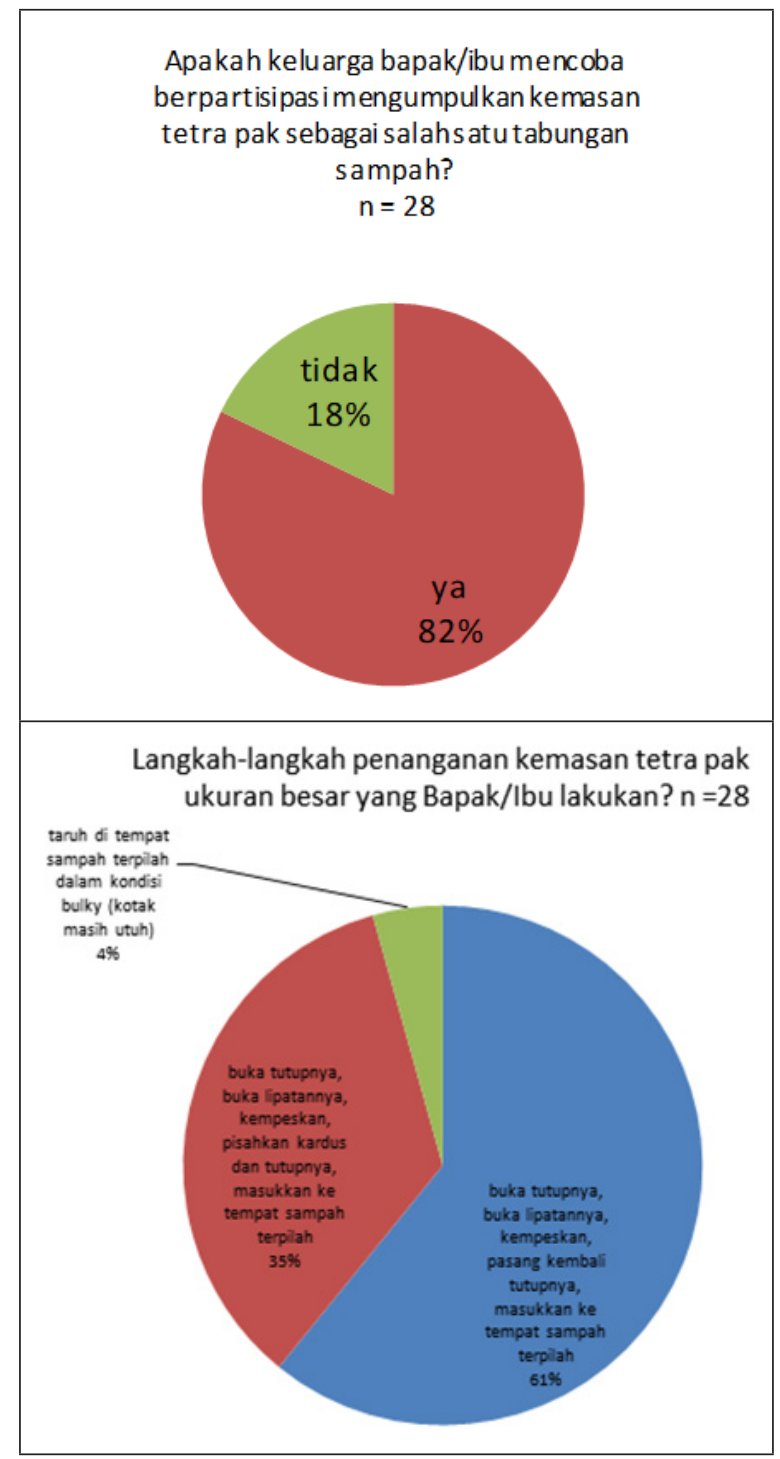

Gambar 7. Hasil Distribusi Partisipasi Keikutsertaan Dalam Kegiatan Pengumpulan Kemasan Tetra Pak dan Praktek $3 \mathrm{~L}$
Pada gambar 8, dapat dilihat hasil pengolahan partisipasi untuk penanganan kemasan tetra pak ukuran karton kecil, terlihat $75 \%$ sudah mengkonfirmasikan bahwa mereka memasukan sedotan kedalam dus, lalu membuka lipatan dan mengempeskannya sebelum ditaruh di tempat sampah terpilah. Hal ini menandakan bahwa warga cukup menyadari bahwa sampah sedotan bisa sekalian didaur ulang di pabrik mitra Tetra Pak, sehingga tindakan ini akan mencegah sampah sedotan yang tercecer di lingkungan. 96\% warga, juga mengkonfirmasi bahwa mereka bersedia menginfokan kepada kenalannya bahwa kemasan tetra pak bisa di daur ulang. Hal ini menandakan bahwa ada bentuk partisipasi lainnya dari warga untuk keberlanjutan kegiatan penangan sampah di lingkungan.

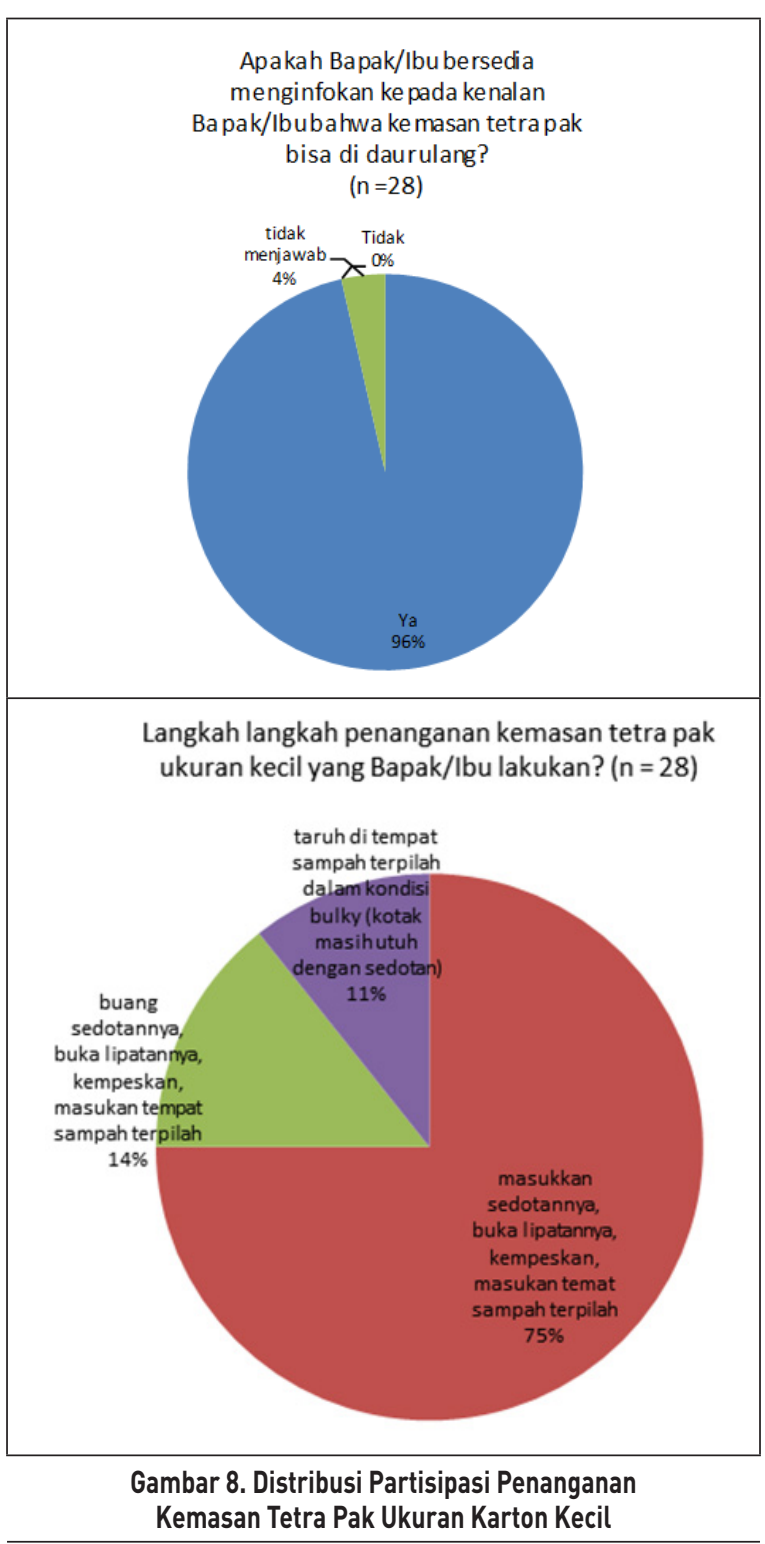




\section{SIMPULAN}

Secara keseluruhan, projek ini cukup berhasil, dikarenakan tujuan tercapai, ada partisipasi dari semua mitra, bahkan beberapa mitra memberikan partisipasinya melebihi target rencana awal. Persepsi bahwa terjadinya suatu perbuatan atau perilaku partisipasi, selain disebabkan karena adanya keinginan aktualisasi diri juga diwujudkan oleh kemampuan partisipan untuk melakukannya. Para partisipan memiliki pengendalian terhadap dirinya untuk leluasa bertindak atau sejauh mana dirinya mampu mengatasi keterbatasan dalam bertindak dan mau bersikap terbuka dalam partisipasi. Partisipan mempunyai keyakinan diri mengenai mudah atau sulitnya mewujudkan hal yang ingin dilakukannya dalam projek, dan ini membentuk persepsi pengendalian perilaku, dimana hal ini selain ditentukan oleh kompetensi partisipan yang bersangkutan, juga oleh ketersediaan sumber daya berupa peralatan, materi dan kesempatan yang mendukung perilaku partisipasi tersebut.

Pengelolaan partisipatoris akan menimbulkan kepercayaan sosial, dan hal ini akan membantu mewujudkan suatu kegiatan mewujudkan sirkular ekonomi. Ada komitmen terhadap rasa kepemilikan bersama, dimana setiap partisipan lebih menyukai pembagian bersama atau saling menguntungkan, yaitu hubungan yang mempertimbangkan kebutuhan dan manfaat. Jika hubungan antara partisipan didasarkan pada kebutuhan untuk saling membantu dan melengkapi, berarti relasi partisipasi akan berjalan normal dan baik, membiarkan nilai-nilai kemanusiaan dan kehidupan bisa dipahami tiap partisipannya, sesuai tahapannya masing-masing. Tetapi sebaliknya, jika suatu relasi partisipasi didasarkan untuk meraih manfaat dari orang lain, maka relasi tersebut akan berjalan tidak normal, karena disertai target dan kepentingan.

\section{PENGHARGAAN}

FORKOM SERPONG TERRACE RT 03, PT. Tetra Pak Indonesia, SampahQu, DPPM Universitas Tarumanagara, Prodi Teknik Industri UNTAR, Inkubator Peduli Sampah Cintai Bumi.

\section{DAFTAR PUSTAKA}

Andreanto, R. (2018). Managing Sustainable Business, slide pada Seminar "Winning the Future Today“. Penyelenggara GAPMMI dan Tetra Pak Indonesia. Sheraton Hotel Gandaria City Jakarta.

Badan Pusat Statistik. (2017). Statistik Lingkungan Hidup I ndonesia. Jakarta.

Geissdoerfer, M., Savaget, P., Bocken, N., and Hultink, E. (2017). The Circular Economy - A new sustainability paradigm?. Jurnal: Journal of Cleaner Production, 143 (1), 757-768. [pdf] <https://doi.org/10.1016/j. jclepro.2016.12.048> [Diakses: 14 Oktober 2018].

Getty, R. (1994). Significance of Approaching Participatory Ergonomics From The Macroergonomics Perspective: A continuous Improvement Process, Advance in Industrial Ergonomics and Safety VI, Edited by F Aghazadeh, Taylor \& Francis.

Hartriani, J. (2016). Article: Ekonomi Melingkar, Solusi Sampah Indonesia. Katadata. Published on 5 September 2016. [online] <https://katadata.co.id/infografik/2016/09/05/ekonomimelingkar-solusi-sampah-indonesia > [Diakses: 8 Oktober 2018].

Kristina, H, J., Christiani, A, Sukania, I W. Ergonomi Partisipasi Dalam Pemberdayaan Bank Sampah Sebagai Kunci Keberhasilan Reverse Logistic Kemasan Tetra Pak. (2019). Teknik Industri UNTAR dan Teknik Industri UPH. paper ilmiah unpublish.

Kristina, H, J., Jobiliong E., Christiani, A. (2018). Model Rantai Pasok Daur Ulang Kemasan Karton yang Mengandung Aluminium Foil, Laporan Penelitian Prodi Teknik Industri UPH, No: P-041-M/FaST/VIII/2018.

Manuaba, A. (23 November 1999). Penerapan Pendekatan Ergonomi Partisipasi Dalam Meningkatkan Kinerja Industri, Laboratorium Fisiologi Fakultas Kedokteran Program Pascasarjana Ergonomi, Universitas Udayana, Disampaikan dalam Seminar Nasional Ergonomi Reevaluasi Penerapan Ergonomi dalam Meningkatkan Kinerja Industri Surabaya. 
Republik Indonesia. (2008). Undang-undang Republik Indonesia No. 18 Tahun 2008 Tentang Pengelolaan Sampah. Lembaran Negara RI Tahun 2008, No. 69. Sekretariat Negara. Jakarta.

Sistem Informasi Pengelolaan Sampah Nasional. (2018). Data Pengelolaan Sampah Umum. Kementerian Lingkungan Hidup dan Kehutanan Republik Indonesia. [online] $<$ http://sipsn.menlhk.go.id/?q=3a-dataumum\&field_f_wilayah_tid $=1405 \&$ field_ kat_kota_tid=All\&field_periode_id_ tid=2168> [Diakses: 17 Agustus 2018].

SumargI, A. (2018). Keynote speech Kepala Seksi Pemantauan Direktorat Pegelolaan Sampah Pada Kementerian Lingkungan Hidup dan Kehutanan Republik Indonesia, rekaman suara pada Seminar "Winning the Future, Today ", yang diadakan GAPMMI dan Tetra
Pak Indonesia, Sheraton Hotel Gandaria City Jakarta.

Susan, C., dan Myers, G. (2014). diterjemahkan oleh Daryatno, Psikologi Konservasi: Memahami dan Meningkatkan Kepedulian Manusia Terhadap Alam, Cetakan 1, Penerbit Pustaka Pelajar.

Vink, P. Imada, A.S. and Zink, K.J. (2008). Defining stakeholder involvement in participatory design processes. Journal of Applied Ergonomics, 39: 519-526.

Wibawa. H. (29 April 2019). Kemasan Plastik, wawancara di WAG Peduli Sampah Cintai Bumi.

Zubaedi, Pengembangan Masyarakat Wacana dan Praktik. (2013). Kencana Prenada Media Group. Badan Standarisasi Nasional (BSN), Standar Nasional Indonesia, Pengelolaan Sampah di Pemukiman, SNI 